\title{
Encouraging Indonesian English Young Learners through Language Games
}

\author{
By \\ Tita RatnaWulandari\&DwiWahyuApriani \\ English Study Program,Universitas BinaDarma, Palembang \\ Email: zaft_forever@yahoo.com
}

\begin{abstract}
Indonesian English Young Learners (IEYL) really close to boredom. Therefore, the teachers are demanded to be as highly creative as possible when they are having classroom activities. To see the recent phenomena, most IEYL feel convenient to study in their English course rather than their school. This is due to the English course provides them with fun, relax, and enjoyable learning environment. In contrast, the school provides the IEYL with monotonous activities. In accordance with this problem, the writer is interested in describing five English games which might be references for school teachers. The problems of this study were: (1) what are the five English games which can help the IEYL in classroom activities? and (2) what are the procedures to apply the games in classroom activities? The findings were descriptively discussed by seeing the literature review. It is found that the games to help IEYL are: (a). Spider Web, (b). Cartoon Color, (c). Find Someone who, (d). Read-Run-Say-Listen-Write, and (e). What is it?
\end{abstract}

Keywords:IEYL, LanguageGames and Classroom Activities

\section{Introduction}

It is a common belief that English must be one of many languages mastered by Indonesians. Thus, government supports it by issuing a policy about English as a local content subject started from the elementary school, as it is noted in The Decree of Ministry of Education and Culture, No: 060/U/1993 issued on February 25, 1993 that English is a local content subject and would be taught from the fourth grade up to the sixth grade pupils. Then, it is also supplied by The Ministry of Education Regulation: 22 Year 2006, issued on May 23, 2006 which 
stated that English teaching must have standardized contents as they are issued from English curriculum as local content subject.

In addition, BSNP cited in Ratmaningsih (2012) that learning English is aimed to reach oral language competency. In practice, school implements English teaching starts from the first grade up to the sixth grade. Parents are also enthusiastically facilitating their children to enroll themselves into an English course.

These above phenomena are due to a common belief that learning a foreign language in early childhood is a better step to be internationally involved in future. However, this can also be a harmful action if the way in learning it does not suit young learners' characters.As a result of it, the learners will feel boredom and neglect the process. This, nowadays, mostly happens in English classrooms. In fact, we can also see that the learners feel more convenient to study at their English courses than school.

One of the causes may come from teacher's failure attemps to determine the use of an appropriate teaching strategy. Indonesian English Young Learners (henceforth IEYLs) need an attractive learning mode.It is the duty of teachers to carefully select the strategy which is suitable to the IEYLs characteristics. IEYLs are characterized as students who need to be attracted with fun and enjoyable learning environment. This is provided by language games.

A game is an activity with rules, a goal, and an element of fun. There are two kinds of games: competitive games, in which players or teams race to be the first to reach the goal, and co-operative games, in which players or teams work 
together towards a common goal (Hadfield, 1996). However, teachers are demanded to be selective in choosing the games used in IEYLs class.

Games offer a wide range activity in classroom. They also provide an opportunity for intensive language practice, offer a context in which language is used meaningfully and as a means to an end, acts as a diagnostic tool for the teachers, highlights the area of difficulty. Last but not least, one of the most important reasons for using games is simply that they are immensely enjoyable for both students and teachers (Hadfield, 1996).

Due to all reasons above, the writers are interested in sharing some information dealing with five language games which can be used in teaching IEYLs. This study discusses two problems. They are: (1). what are the five language games which can help the IEYLs in classroom activities?, and (2) what are the procedures to apply the games in classroom activities?. To answer those two problems, the writers will descriptively explain the five games. The writers, actually, have already applied those five games in their classroom activities.

\section{Why Games?}

According to Wright, et. all. (2006), there are four reasons why teachers should use games in their activities.

1. Language learning is hard work

Learners must do hard effort and attempt to understand the language, repeat the lesson accurately, adapt and use newly understood language in 
conversation and in written composition. Then, the effort must be maintained over a long period of time. To help the maintenance games contribute a lot.

2. Experiencing language

Games also help the teacher to create the contexts in which the language is useful and meaningful. Learners will try to use the language and take part in oral or written communication. Games provide one way of helping the learners to experience language rather than merely study it.

3. Repeated use of language items

Many games cause as much use of particular language items as more conventional drill exercises. The contribution of drill exercises lies in the concentration on a language form and its frequent occurrence during limited period of time. By making language convey information and opinion, games provide the key features of 'drill' with the added opportunity to sense the working of language as living communication. Games involve the emotions and the meaning of the language is thus more vividly experienced. It is, for this reason, probably better absorbed than learning based on mechanical drills.

4. Central to learning

If it is accepted that games can provide intense and meaningful practice of language, they must be regarded as central to language teachers' repertoire and not merely a way of passing the time. 
Frist Game \#Spider Web

Type of activity : whole class; vocabulary size

Language : vocabulary and pronunciation

Preparation : list of vocabulary; setting of place

Procedure

a. Set chair into circle shape and only use chair as the number of the students (minus one) in the class. So, there will be one student who does not have seat. For example, if there are ten students, there are only nine chairs in the room.

b. Group the students into four or five. Name the groups by the vocabulary focus provided. For example, if the focus is animals, teacher must provide the students with certain words dealing with animals such as: rhinoceros, hippopotamus, and goat (give them the animals which they haven't learned previously).

c. Tell the students if their group's name is called the group members need to find new seat. The one who does not have seat must mention five new animals exclude his/her group's name. Then, she/he mentions another group's name.

Note: if spider is called, it means all groups must find new seat.

Second Game \#Cartoon Color

Type of activity $\quad$ : individual work

Language : vocabulary

Preparation $\quad$ : list of vocabulary; coloring pen; cartoon picture 
Procedure

a. Tell the students colors word which are used in the cartoon color.

b. Ask them to color the picture based on the instruction given (Appendix 1).

Third Game \#Find Someone Who

Type of activity : whole class; information search

Language : asking and answering questions to get information about peers

Preparation $\quad$ : think of topics you would like the learners to explore

Procedure

a. Write several instructions on the board. The conventional way of doing this is to use the phrase Find someone who..., for example, find someone who drink milk in the morning, eat fried rice in the morning, take a bath in the morning, and soon. However, teachers need to adjust the sentences used based on their students comprehension.

b. Provide the students with guideline questions which will help them to play the game. (see Appendix 2)

c. Ask the students to do the activity and give time limit in order to avoid boredom. Teacher can also just provide the instructions without giving the guideline questions if the students are ready for it. 
Fourth Game \#Read-Run-Say-Listen-Write

Type of activity : whole class; spelling check

Language $\quad$ : integrated four language skills

Preparation $\quad$ : list of words or short readings

Procedure

a. Group the students if you have big class or just pair the students if you have small class.

b. Tell the students to have one writer in their group and the rest of them will be readers who read passage or word.

c. Give some distance between the writer and readers. Hopefully, there is a space for the readers to run to see their writers.

d. Put the word list or short story in a place provided. The following is the example of short story and word list:

\begin{tabular}{|c|c|}
\hline Short Story & Word List \\
\hline Angela and Tom sit. Tom brings a & 1. Sit \\
\hline big bag. Angela brings a small bag. & 2. Big \\
\hline Tom brings a black hat. Angela & 3. Bag \\
\hline brings a pink hat. Tom brings an old & 4. Small \\
\hline map. Angela brings a big map. Tom & 5. Black hat \\
\hline brings a net. Angela brings a big net. & 6. Pink hat \\
\hline Angela and Tom bring many things. & 7. Old map \\
\hline Tom brings a jug. Angela brings & 8. Bring \\
\hline mugs. Tom and Angela drink. & 9. Net \\
\hline
\end{tabular}




\begin{tabular}{|l|l|}
\hline Taken from: & 10. Things \\
http://www.really-learn- & \\
english.com/english-short-stories- & \\
level-02-story-02.html & \\
\hline
\end{tabular}

e. Ask the readers to line behind it.

f. Tell the readers to read carefully and memorize the words, they have to run and say the sentences to the writers. The writers write the sentences or words told by their readers.

g. At the end, the teacher rereads the sentences and words and the students check their work. The group which makes the least mistakes is the winner.

Fifth Game \#What is It?

Type of activity $\quad$ : group or individual work

Language : integrated four language skills

Preparation $\quad:$ list of words

Procedure

a. Ask one student to come forward (as speaker) and describe the word given.

For example, the word given is cat. Then, she/he must describe the word in English such as it is an animal, it has four legs, and soon.

b. Ask the rest students to guest what is it?

c. Tell the rest students that they can question the speaker. 


\section{Conclusion}

The use of games and kinestetic activities in the classroom has been proven as effective ways to trigger IEYLs' interest in learning English. Many teachers and reserachers have progressively introduced us to such activities. As a teacher we should aware of this phenomenon because we will be more useful to our students when we are equipped with appropriate tools that can promote an enjoyable and meaningful learning. Young learners have the advantage of not being constantly astounded by what adults tell them. They learn in the context of specific examples such as well prepared language games which offers rich territory for two-way educational exchanges between students and peers or teachers and students. Teachers have much to learn about how their students navigate, select, and use such an activity. In return, teachers have the capacity to enrich the curiousity to their students as they explorethe learning journey. It is worth looking closely at what the contemporary literacy scenes may offer us in terms of possibilities of practical activity as well. In the face of such innovations and creativities, teaching language especially to IEYLS would be a richer and more complex challenge than we expected before. 


\section{References:}

Hadfield, Jill. 1996. Advanced Communication Games. Essex, EN: Addison Wesley Longman.

Ratmaningsih, Ni Made. 2012. Scripted Songs to Teach English for Young Learners. Proceedings of the $59^{\text {th }}$ TEFLIN International Conference.

Rosyidah, A. -.Some Considerations to Implement English for Young Learner (EYL) in Indonesian Society.Unpublished Paper Presented in English Teacher Training at BDK Surabaya.

Wright, A., David Betteridge, and Michael Buckby. 2006. Games for Language Learning. Cambridge, UK: Cambridge University Press. 
Appendix 1.Cartoon Color

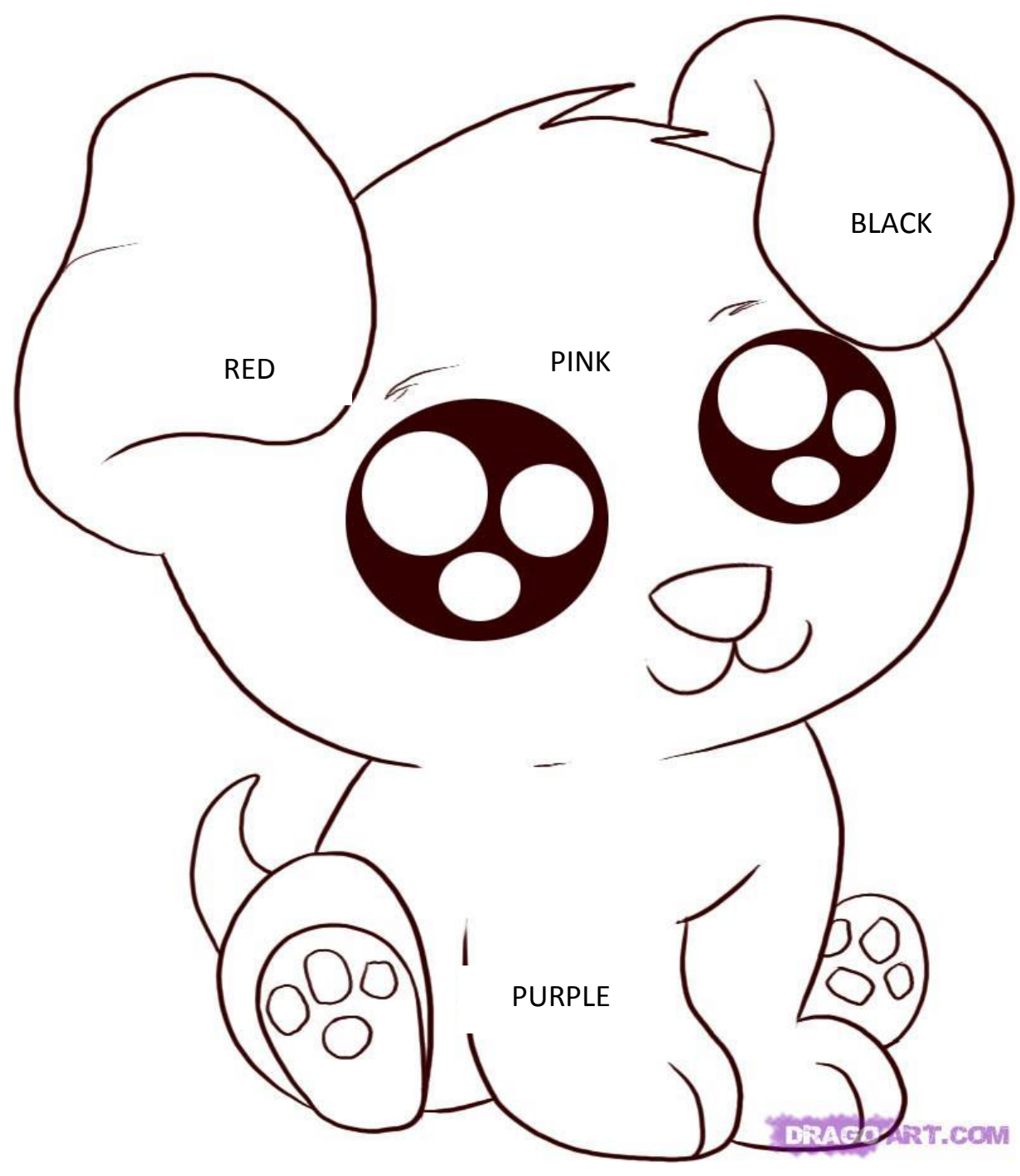

BROWN

\section{$\underline{\text { Taken from: }}$}

http://www.dragoart.com/tuts/1800/1/1/how-to-draw-an-anime-cartoon-puppy.htm 
Premise Journal Vol 4 No I April 2015 ISSN: 2442-482x (cetak) ISSN: 977244248003 (electronic)

Appendix 2. Find someone who worksheet.

\begin{tabular}{|c|c|c|}
\hline \multicolumn{3}{|c|}{ Find someone who......... } \\
\hline No & Questions & Names \\
\hline 1 & Do you drink milk in the morning? & \\
\hline 2 & $\begin{array}{l}\text { Do you eat fried rice in the } \\
\text { morning? }\end{array}$ & \\
\hline 3 & Do you take a bath in the morning? & \\
\hline 4 & $\ldots .$. & \\
\hline
\end{tabular}

Note: Names column is for the students who answer 'yes' 